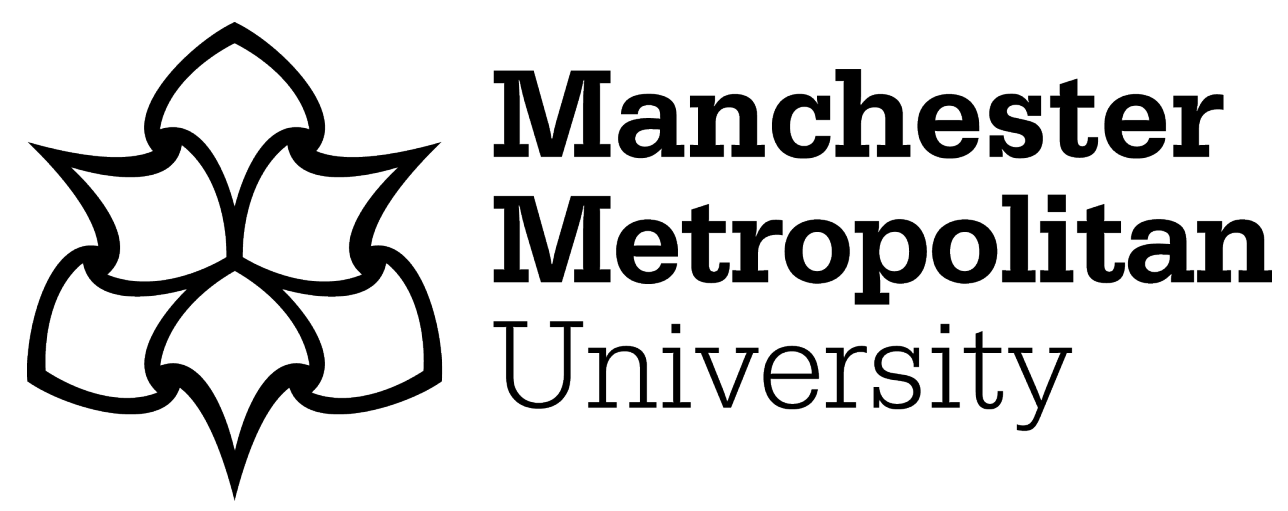

Salvia, AL, Brandli, LL, Leal Filho, W and Locatelli Kalil, RM (2019) An analysis of the applications of Analytic Hierarchy Process (AHP) for selection of energy efficiency practices in public lighting in a sample of Brazilian cities. Energy Policy, 132. pp. 854-864. ISSN 0301-4215

Downloaded from: https://e-space.mmu.ac.uk/623698/

Version: Accepted Version

Publisher: Elsevier

DOI: https://doi.org/10.1016/j.enpol.2019.06.021

Usage rights: Creative Commons: Attribution-Noncommercial-No Derivative Works 4.0

Please cite the published version 


\title{
An Analysis of the Applications of Analytic Hierarchy Process (AHP) for selection of Energy Efficiency practices in Public Lighting in a sample of Brazilian cities
}

\author{
Salvia AL, Brandli LL, Leal Filho W, Locatelli Kalil RM \\ Energy Policy 132:854-864 01 Sep 2019 DOI \\ https://linkinghub.elsevier.com/retrieve/pii/S030142151930391X
}

\begin{abstract}
In Brazil, the public lighting sector is a responsibility of the municipal government and typically represents around $4 \%$ of the electricity consumed by cities. Considering the significant importance and functions of this service, sustainable management is necessary. The aim of this paper is to investigate the main practices used worldwide in terms of energy efficiency of public lighting and propose the use of the multi-criteria method called Analytic Hierarchy Process to choose the best options for a group of Brazilian cities, namely Passo Fundo, Santa Maria and Porto Alegre. The methodology of this paper consists of searching for best practices in public lighting, which worked as alternatives for applying the Analytic Hierarchy Process. The final step consisted of presenting the impacts of a potential implementation, through analysis of energy and financial savings. The results suggest the preferred practices to each municipality (Audit and Guide Elaboration, Retrofit, Alternative Energy and Management) and their potential implementation can promote energy and financial savings up to 6 $\mathrm{GWh} /$ year and $600,000.00 \mathrm{US} \$ /$ year. The main implications of this paper are related to proposing the use of a multi-criteria method to the public lighting sector and providing useful insights for local governments and especially for developing countries.
\end{abstract}

Keywords: sustainable development, energy management, lighting, sustainable cities, best practices.

\section{Introduction}

The sound development of urban infrastructure has become one of the most pressing challenges facing the world today, and public lighting systems play a significant role within 
this field. Public lighting systems have a prominent role in providing quality of life to urban centers, acting as an instrument of citizenship, contributing to social and economic development, as well as benefitting public safety, traffic, crime prevention and providing value to the urban environment and leisure areas (Cambraia, 2003).

This research has been motivated by the fact that despite all the functions and importance of public lighting, more attention is paid to researches focused on energy efficiency at household or industries (Charlier, 2015; Havas et al., 2015; Kavousian et al., 2015; Özkara and Atak, 2015; Peng et al., 2015; Webber et al., 2015), mainly due to the higher energy consumption. Or yet, when there are publications in the area of public lighting, these tend to be much more related to technical questions rather than to its sustainable management (Fonseca et al., 2015; Green et al., 2015; Kostic and Djokic, 2009; Miguel, 2014; Peña-Garcia et al., 2015; Rabaza et al., 2013; Rabaza et al., 2016). However, public lighting is a sector that needs more attention by the management and has much to contribute allied with the search for efficiency and sustainability.

Despite numerous advantages, public lighting can present a high waste of electricity caused by the use of inadequate equipment and poor management. Energy consumption of public lighting may, at first, seem negligible in the face of global consumption, and so cities largely do not control the actual energy consumption of the sector. Fewer resources are devoted, therefore to cost analyses and studies of the feasibility of energy efficiency measures in this area. Thus, energy efficiency programs in this field are very welcome, as there are several options for saving energy, some of which allow for reductions of up to $50 \%$ when it comes to electricity consumption (Lobão et al., 2015).

The contribution of this work is related to the fact that there are currently several energy efficiency practices in public lighting applied in the world, but an in-depth study is required when a municipality wishes to select which one to implement. This is especially the case when 
many of these municipalities are below ideal standards in terms of the public lighting service provided in comparison to the standards observed in countries which have already successfully implemented such practices.

In this sense, this paper aims to investigate the main practices used worldwide in terms of energy efficiency of urban public lighting and propose the use of the AHP multi-criteria method to choose the best options for a group of Brazilian cities. Aligned with this aim, the importance of this paper is twofold: from a practical point of view, it proposes the use of a consistent methodology to the public lighting sector, and from a theoretical point of view, it discusses practices that could be applied in it to improve energy efficiency. The novelty and implications for research range from filling the gap of the literature when it comes to addressing public lighting in the perspective of sustainable management and the proposal of the AHP multicriteria method to this sector, providing useful insights for local governments and especially for developing countries.

This paper is organized as follows: in addition to the introductory section with two subsections on importance of sustainable public lighting and multi-criteria decision making, the methodology used in this article is explained in Section 2. In this section, each one of the three steps of this research are described. Then, the results are shown in Section 3, according to the best practices researched and case studies presented. In Section 4, conclusions and policy implications are drawn.

\subsection{Importance of sustainable public lighting}

The main purposes of public lighting are to protect people and property, promote an improved quality of life and safety, contribute to social and economic development and prevent crime, all of which add significant value to the urban environment (Cambraia, 2003). Irsyad 
and Nepal add that this public lighting systems also support night-time economic activity and also encourage new developments (Irsyad and Nepal, 2016).

Local governments generally have limited budgets to provide this infrastructure properly. In addition, increasing societal pressure to protect the environment - and for municipalities to meet climate change targets - contributes to the need of improved sustainability in public lighting systems.

Each year, countries consume large amounts of energy in their public lighting systems. An excellent parameter to measure sustainability is energy efficiency and, in recent years, efficiency in public lighting installations has become an important area of study (Rabaza et al., 2013).

Sustainability in public lighting encompasses the search for optimal lighting solutions, reaching all of the functions of the system, reducing operational expenses and minimizing electricity consumption, especially through use of more efficient lamps, telemanagement and power control (Kostic and Djokic, 2009; Djuretic and Kostic, 2018). This conceptualization precisely addresses the three axes of sustainability: environmental, economic and social. Environmental sustainability in public lighting is about reducing consumption, therefore demanding less use of natural resources and emitting smaller amounts of $\mathrm{CO}_{2}$. Economic sustainability focuses upon the reduction of spending on consumption, and management planning enables investment that contributes to the improvement of the entire system and cities as a whole. Finally, social sustainability emphasizes efficiency in the system that serves the functions of the sector and the existence of a quality service for the entire population.

Irsyad and Nepal (2016) estimated the national benefits in Indonesia that arose from energy efficiency improvements in street lighting systems based on a pilot project in Jakarta and energy audits in other three cities. The authors concluded that investments in electricity 
conservation for street lighting will be returned within 2.9 years on average, although the energy company service did not consider it.

Radulovic et al. (2011) point out that the sustainable energy management of cities can be viable and environmentally responsible at the same time. It can also be said that management represents a driving force for projects towards success in public lighting, as well as encouraging the idea of developing a sustainable future for society as a whole.

\subsection{Multi-criteria decision making}

Currently, a number of energy efficiency initiatives in street lighting are being applied worldwide with the aim to reduce environmental impacts and improve sustainability performance (Kostic and Djokic, 2009; Becalli et al., 2015) as well as a tool towards energy security (Leal Filho and Voudouris, 2013). However, it is important to define criteria and a specific method to decide which one to apply in any given region.

Indeed, the type of initiative to be applied in each city or region depends on a number of factors such as:

a) Their sizes

b) The public lighting structure, which may be centralized for the whole city, or managed at the district level

c) The status of the utilities: private or public owned

In other words, the development of energy efficiency initiatives needs to be commensurate with the unique needs seen in each city, and the judgment of those responsible for managing the sector in the area. As the selection and prioritization of practices is not simple, the use of decision-making processes, for example, could assist in achieving satisfactory results.

Specific methods should be followed in a decision-making process, one of which is multicriteria decision making. This is a process to assist organizations to evaluate the available 
information, weigh all of the possibilities and reduce the risk of disappointment after a decision is made (Belton and Stewart, 2002). Used in many different areas and with increased application in the last couple of decades, this method of decision making has allowed for more complex decision analysis methods, including the use of technologies and support to real-world decisions (Hamurcu and Eren, 2019).

As presented by Yagmur (2016), there are many methods that use the multi-criteria decision-making process, such as AHP, TOPSIS, PROMETHEE and EVAMIX. The AHP is very commonly used to select technologies in modern scientific research (Tang et al., 2014; Kurka, 2013). This method provides an easy and efficient determination of the relative weight of multiple factors for a comprehensive evaluation problem, and it also has the advantage of permitting a hierarchical structure of the criteria. This provides users with a better focus on specific criteria and sub-criteria (Sui et al., 2016; Franek and Kresta, 2014).

The AHP method is one of the most popular decision support tools because of its simplicity and the possibility of being used for decision-making groups, involving multiple actors, scenarios and decision elements. It was developed by Thomas L. Saaty in the 1970s and has since been applied in several contexts, from social studies and technology, to health and environmental issues (Jovanović et al., 2015; Emrouznejad and Marra, 2017).

As stated by Ramanathan (2004), the field of energy has a number of issues that require analysis considering several criteria, therefore research in the area of multi-criteria decision making became a growing field in the last years and has been applied to a number of energyrelated problems. It includes papers on decision making for renewable energy investments (Strantzali and Aravossis, 2016; Ulloa et al., 2018), for local energy planning (Marinakis et al., 2017), for energy performance of buildings (Silva et al., 2016), and for selection of different energy systems (Dai et al., 2019), most of these using or acknowledging the AHP method. 
Specifically in the context of public lighting, some examples of the use of multi-criteria decision making include the application to rank technical alternatives, to identify sets of optimal retrofit actions and support municipalities and their local decision makers (Carli et al., 2018; Carli et al., 2019; Cristea et al., 2018). However, there is a lack of studies focusing on the use of the AHP method in this sector and with particular emphasis in sustainable management rather than in technical aspects.

\section{Methodology}

In this section, the processes carried out during this study are presented. This is structured as follows: first, section 2.1 presents the search for best practices and explains how they were classified; section 2.2 focuses on describing the Analytic Hierarchy Process, including details about the method, studied municipalities, criteria used, description of the group of decision-makers, and the analyses performed to ensure reliability; finally, in order to represent the impact of the potential implementation of the chosen practices in the three municipalities, section 2.3 briefly explains the last step of the research, which is the use of an energy savings calculator to simulate different scenarios for each city.

\subsection{Search for best practices}

The concept of best practice includes technological innovations, new ways of using natural resources, new working methods or tools, new forms of collaboration between stakeholders, or a combination of these. Best practice should generate positive results for the environment and also, preferably, for the economy and society in general (European Commission, 2005). A best practice example must have been implemented and have subsequently generated good results, so its concept also includes expressions such as "good examples" and "good practices". 
Brazil has been adopting practices of developed countries in order to implement actions of energy efficiency. Considering that, the research of best practice in energy efficiency management in public lighting used sources such as official documents of energy agencies; materials on projects developed by Siemens, which is a leading company in the manufacture of various types of materials (including public lighting) and a provider of solutions for several sectors (Gracioso and Najjar, 2001); recommendations of the World Bank through the TRACE tool (ESMAP, 2013) and reports published by the energy information website Procel. In addition to these sources, databases were also used to search for national and international papers on the subject.

Figure 1 shows the distribution of case studies used during the research. The black markers represent cities or countries that have been applying different types of practices in order to seek energy efficiency in public lighting.

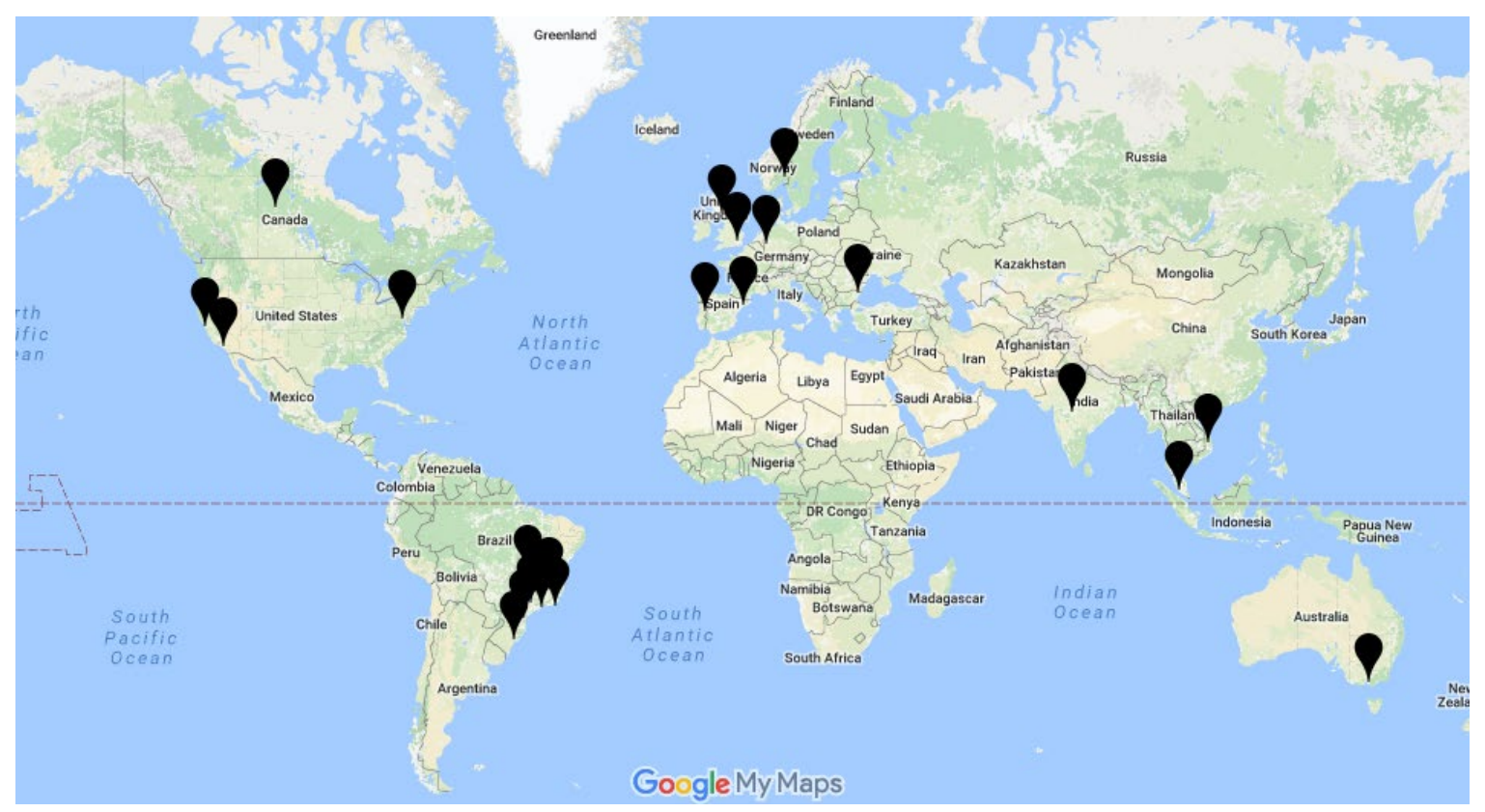

Fig. 1. Distribution of case studies in the world

After finding these examples of global best practices, they were organized into four types of programs, according to their objectives, impacts and similarities of actions. Subsequently, 
these programs were classified according to aspects described by Abdmouleh et al. (2015). These aspects, according to the authors, regulate the success of the development and integration of renewable energy practices, and in this paper, the same aspects have been adapted to evaluate best practice in the area of public lighting, according to Table 1.

\begin{tabular}{|c|c|}
\hline Aspects & Description \\
\hline Political & Actions that need political support for implementation, such as national plans. \\
\hline Fiscal & $\begin{array}{l}\text { Actions that involve fiscal support for implementation, such as the inclusion of } \\
\text { penalty rates or reduction of rates as a bonus. }\end{array}$ \\
\hline Financial & $\begin{array}{l}\text { Actions that require financial incentives for implementation, such as forms of } \\
\text { financing and public or private support. }\end{array}$ \\
\hline Legislative & $\begin{array}{l}\text { Actions that depend on legal adjustments and / or incentives, such as changes in } \\
\text { tariffs and consumption limitations. }\end{array}$ \\
\hline $\begin{array}{l}\text { Technological and } \\
\text { environmental }\end{array}$ & $\begin{array}{l}\text { Actions dependent on projects and research in the technological and environmental } \\
\text { area }\end{array}$ \\
\hline
\end{tabular}

Table 1. Classification of best practices according to the aspects that regulate their success

\subsection{Analytic Hierarchy Process (AHP)}

Some authors have already used AHP to evaluate energy efficiency issues in several areas, such as the selection of solar panels for photovoltaic systems (Balo and Şağbanşua, 2016), the identification of energy efficient solutions for ship operations (Beşikçi et al., 2016), and the choice of preferences for different energy sources in countries (Ishizaka et al., 2016). According to Kumar et al. (2017), AHP is among the multi criteria decision making techniques mostly preferred for ranking energy technologies and applied in energy planning. Its strengths include being simple, flexible and not involving complex mathematics, besides being widely and successfully applied in practice (Ramanathan and Ganesh, 1995). On the other hand, some disadvantages of this method include the high computational requirement even for small problems, having a subjective nature and relying on emotions to be transferred to numerical 
judgments and the increased time and effort demanded for bigger amount of pair comparisons (Karthikeyan et al., 2016; Oguzitimur, 2011).

When compared to other options, AHP tends to be more acceptable by decision makers who lack familiarity with decision-making methods and it has higher preference when used for large number of comparisons and on a subjective scale (Bard, 1992). Taking these advantages into consideration, its great acceptability in the academic environment, and the availability of the software Expert Choice 11 for the decision-making process, the AHP method was the chosen one for this analysis.

The methodology is based on a square matrix $\mathrm{n} x \mathrm{n}$, where the rows and columns correspond to the $\mathrm{n}$ criteria analyzed for the problem in question. Thus, the value $\mathrm{a}_{\mathrm{ij}}$ represents the relative importance of the criterion of line $i$ against the criterion of column $j$, and the same is valid for the evaluation of alternatives (Zambon et al., 2005).

As stated by Aragonés-Beltrán et al. (2014), the n criteria and alternatives in the same level are compared using Saaty's Fundamental Scale, composed by the relation of a numerical scale and a corresponding verbal definition, according to Table 2 (Saaty, 1994). For each level a pairwise comparison matrix $\mathrm{A}$ is obtained based on the decision maker's judgments $\mathrm{a}_{\mathrm{ij}}$ (Equation 1).

$$
A=\left[\begin{array}{cccc}
1 & a_{12} & \cdots & a_{1 n} \\
a_{21} & 1 & \cdots & a_{2 n} \\
\vdots & \vdots & \ddots & \vdots \\
a_{n 1} & a_{n 2} & \cdots & 1
\end{array}\right], \text { where } \mathrm{a}_{\mathrm{ji}}=1 / \mathrm{a}_{\mathrm{ij}} \mathrm{i}, \mathrm{j}=1, \ldots, \mathrm{n}
$$

\begin{tabular}{cc}
\hline Intensity of importance & Definition \\
\hline 1 & Equal importance/preference \\
3 & Moderate importance/preference \\
5 & Strong importance/preference \\
7 & Very Strong importance/preference \\
9 & Extreme importance/preference \\
$2,4,6,8$ & Intermediate values of judgment \\
\hline
\end{tabular}

Table 2. Saaty's fundamental scale 
The evaluation can then be done in different types of software, but a specific one for the method is indicated for problems with many alternatives and/or criteria. After the attribution of weights, it is necessary to verify the consistency ratio of the study and a sensitivity analysis must also be done (Aragonés-Beltrán et al., 2014).

In order to check judgment inconsistencies, the CR (Consistency Ratio) of matrix A is used. The Consistency Ratio is given by CR $=\mathrm{CI} / \mathrm{RI}$, where $\mathrm{CI}=\left(\lambda_{\max }-\mathrm{n}\right) /(\mathrm{n}-1)$ and $\lambda_{\max }$ is the maximal eigenvalue of A. The RI (Random Index) is an experimental value which depends on $n$, as presented on Table 3, from Saaty (1994). If CR is less than a threshold value then the matrix can be considered as having an acceptable consistency, and the derived priorities from the comparison matrix are considered meaningful. On the other hand, if CR exceeds the threshold value, the judgments in matrix A should be reviewed (Aragonés-Beltrán et al., 2014).

\begin{tabular}{ccccccccccccc}
\hline $\mathrm{N}$ & 1 & 2 & 3 & 4 & 5 & 6 & 7 & 8 & 9 & 10 & 11 & 12 \\
\hline $\mathrm{RI}$ & 0 & 0 & 0.52 & 0.89 & 1.11 & 1.25 & 1.35 & 1.40 & 1.45 & 1.49 & 1.51 & 1.54 \\
\hline
\end{tabular}

Table 3. RI values

The use of the AHP method can be summarized in four steps (Saaty, 2008). The first step is to define the problem. The second step is to structure the decision hierarchy. The top of the decision hierarchy structure should be the goal of decision, followed by the objectives, and, at the lowest level, the alternatives. The third step is to construct a set of pairwise comparison matrices, when the criteria are compared against each other. The final step is to use the priorities obtained from the comparisons to weigh the priorities for each alternative.

\subsubsection{Studied municipalities}

According to data from the Brazilian Institute of Geography and Statistics, Brazil (which is the world's fifth largest country in land mass) has a population of approximately 206.9 
million (Brazilian Institute of Geography and Statistics, 2015). The World Bank (2015) states that the Brazilian Gross Domestic Product (GDP) reached US\$ 1,775 trillion in 2015, representing a yearly Gross National Income of US\$ 9,850 per capita. This is lower than many EU countries, but much higher when compared to other countries in the Latin American region.

The Brazilian Yearbook of Electricity points out that, in 2014, the electricity consumption of public lighting in Brazil was around 4\% of total electrical consumption (Energy Research Enterprise, 2015), compared to 10\% in Germany. The figures in Brazil could be even larger if this service was improved and provided for all of the Brazilian population. Energy efficiency measures in public lighting could therefore improve the situation and represent a way of saving energy and reducing wasted energy.

The municipalities studied were Passo Fundo, Porto Alegre and Santa Maria, chosen due to their importance in the Brazilian region where they are located. Prior studies concerning energy efficiency and public lighting indicators in these cities have shown that they represent the overall reality of Brazilian cities (Salvia, 2016). Table 4 presents some general information about them and also data about their public lighting system.

\begin{tabular}{crcccc}
\hline City & $\begin{array}{c}\text { Area } \\
\left(\mathrm{km}^{2}\right)\end{array}$ & $\begin{array}{c}\text { Population } \\
\text { (inhab.) }\end{array}$ & $\begin{array}{c}\text { Average monthly } \\
\text { electricity } \\
\text { consumption } \\
\text { (kWh/pole) }\end{array}$ & $\begin{array}{c}\text { Number of existing } \\
\text { lighting points per } \\
\text { capita (poles/inhab.) }\end{array}$ & $\begin{array}{c}\text { Percentage of } \\
\text { LED bulbs in } \\
\text { street lighting } \\
(\%)\end{array}$ \\
\hline Passo Fundo & 783.4 & 184,826 & 48.31 & 0.11 & 2.4 \\
Porto Alegre & 496.7 & $1,409,351$ & 60.15 & 0.06 & 0.3 \\
Santa Maria & $1,781.8$ & 261,031 & 43.44 & 0.09 & 2.5 \\
\hline
\end{tabular}

Table 4. Characteristics of each studied municipality

Regarding the consumption of electricity per pole, Porto Alegre is the city with the highest observed value, possibly due to the lower percentage of LED lamps used in public lighting. It is also the city with the lowest number of lighting points per capita, while Passo Fundo and Santa Maria have higher values. 
To a greater or lesser degree, all municipalities have been implementing more efficient luminaires, either by replacing bulbs or adding new poles. The criterion for choosing the distribution of these investments is simple: the municipality introduces new poles and bulbs in those areas with a greater flow of people, vehicles and public transportation. Naturally then, most of the population has better access to this new infrastructure and tends to have a greater potential for savings. The use of LED technology is not yet a reality in cities, as these are only beginning to be introduced into the system as a whole. In fact, there is a smaller share of LED markets in Latin America in comparison to other regions (De Almeida et al., 2014).

The use of alternative energy in public lighting does not yet occur in these cities (Salvia, 2016), and although there is a certain interest in the use of this technology, it largely does not happen due to the high investment demanded.

\subsubsection{Hierarchical structure model}

This methodology initially requires the definition of an objective to guide the analysis, which is defined as the choice of best practice to be implemented in each municipality. Further, criteria are defined to evaluate these practices. They are: the cost of the implementation of the practice; the electrical energy savings that it would represent if implemented; and the ease of implementation. The selection of these criteria was based on and adapted from two main sources: the TRACE tool (ESMAP, 2016) and the International Energy Agency's Promoting Energy Efficiency Best Practices in Cities program (Jollands et al., 2008), which suggest criteria or attributes to rate energy efficiency practices in cities, ranging from energy savings potential and initial implementation cost, to speed/timeframe of implementation to return on investment and transferability.

According to Doumpos and Grigoroudis (2013), when using the AHP method, the number of judgments that must be made by decision makers increases alongside the number of selected 
criteria and alternatives. In addition, the higher the number of criteria, the greater the number of comparisons that should be made, and this may also cause greater inconsistency within the results (Franek and Kresta, 2014). These arguments, along with the importance of using common terms to guarantee clear understanding and avoid hard questionnaires which could lead to high level inconsistence, contributed to the definition of three criteria for this work. Figure 2 presents the hierarchical structural model used in this study.
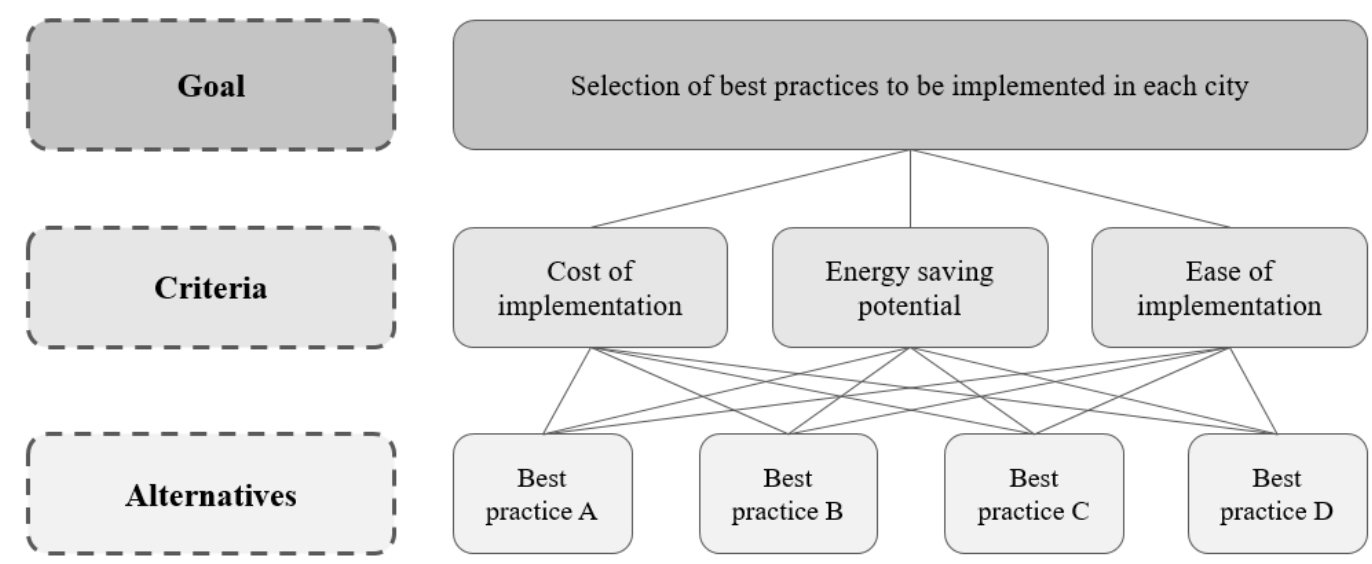

Fig. 2. Hierarchical structural model of this study

\subsubsection{Pairwise comparisons made by experts}

For the comparisons between criteria and the comparisons between the alternatives related to each criterion, Saaty's fundamental scale was used (Saaty, 1994). An online questionnaire was prepared and sent to public lighting experts in each city. This questionnaire contained the pairwise comparisons, in which the experts had to compare criteria and alternatives in pairs, in order to judge their preferred option.

The public lighting experts were municipality technicians from the public lighting sector and professors of Electrical Engineering with expertise in the subject, as presented in Table 5. The common background of these experts is engineering and they share experience in public lighting, which were important conditions to ensure proper understanding of the questionnaire 
and the proposed practices. It was not possible to have the same number of experts in each municipality because it depended on the availability of technicians and professors.

\begin{tabular}{|c|c|c|c|c|c|c|}
\hline \multicolumn{2}{|c|}{$\begin{array}{c}\text { Municipality/ } \\
\text { Expert }\end{array}$} & Gender & Age group & Professional qualification & Job & $\begin{array}{c}\text { Time in Current } \\
\text { Position }\end{array}$ \\
\hline \multirow{6}{*}{$\begin{array}{l}\text { Passo } \\
\text { Fundo }\end{array}$} & 1 & M & $42-51$ & Electrical engineering & $\begin{array}{l}\text { Engineer and } \\
\text { professor }\end{array}$ & 28 years \\
\hline & 2 & M & $33-41$ & Electrical engineering & $\begin{array}{c}\text { Project engineer and } \\
\text { professor }\end{array}$ & 10 years \\
\hline & 3 & M & $26-32$ & Electrical engineering & Professor & 5 years \\
\hline & 4 & M & $26-32$ & Electrical engineering & Professor & 4 years \\
\hline & 5 & M & $33-41$ & Electrical engineering & Engineer (City Hall) & 5 years \\
\hline & 6 & M & $18-25$ & Electrical engineering & Engineer & 8 months \\
\hline \multirow{3}{*}{$\begin{array}{l}\text { Porto } \\
\text { Alegre }\end{array}$} & 7 & $\mathrm{~F}$ & $42-51$ & Electrical engineering & $\begin{array}{l}\text { Engineer - Purchasing } \\
\text { sector (City Hall) }\end{array}$ & 5 months \\
\hline & 8 & M & $26-32$ & Electrical engineering & $\begin{array}{c}\text { Project engineer and } \\
\text { professor }\end{array}$ & 1 year \\
\hline & 9 & M & $33-41$ & Electrical engineering & Engineer (City Hall) & 7 years \\
\hline \multirow{8}{*}{$\begin{array}{l}\text { Santa } \\
\text { Maria }\end{array}$} & 10 & M & $26-32$ & Electrical engineering & Professor & 4 years \\
\hline & 11 & M & $26-32$ & Electrical engineering & Professor & 6 years \\
\hline & 12 & M & $42-51$ & Electrical engineering & Professor & 20 years \\
\hline & 13 & M & $33-41$ & Electrical engineering & Professor & 12 years \\
\hline & 14 & M & $33-41$ & Electrical engineering & Professor & 8 years \\
\hline & 15 & M & $33-41$ & Electrical engineering & Professor & 7 years \\
\hline & 16 & M & $42-51$ & Electrical engineering & Professor & 15 years \\
\hline & 17 & M & Acima 52 & Civil Engineering & Director (City Hall) & 8 years \\
\hline
\end{tabular}

Table 5. Background of the participants

After receiving the completed questionnaires, the Expert Choice 11 software was used to obtain the results. The use of this software allows the combination of individual judgments leading to a combined final result for each municipality.

\subsubsection{Consistency and Sensitivity Analysis}


Through the results generated by the software, the discussion of the results includes consistency and sensitivity analyses. The first one concerns the verification of the consistency ratio of the judgments made, which, according to Saaty (1991), should be less than 0.10 , in order to indicate confidence in the judgment made. Otherwise, comparisons should be reevaluated by the experts. However, according to Scala et al. (2010) and Briozo and Musetti (2015), a consistency ratio with a limit of 0.10 is within Saaty's guidelines, and higher values do not indicate an error in the method, but rather suggest a just data variation which caused an inconsistency. Further, these authors point out that using a consistency ratio of 0.20 as the upper limit still ensures reasonable results when the final judgments are combined.

When a questionnaire is applied to several experts to state their views on a given topic, it is not always possible to ask them to review their judgments in the event of inconsistencies (in order to improve the ratio), and keeping all of their comparisons clear and consistent may present a certain level of difficulty when making several judgments. For this reason and considering that the individual judgments were also combined in this study, the value of consistency ratio was considered as 0.20 .

In addition to the consistency analysis, the sensitivity analysis verifies the variation of the results if there were changes in the criteria judgments. For a result to be considered reliable, it is necessary that even with a little variation in the criteria weight, the result of best practice chosen should be the same (Aragonés-Beltrán et al., 2014).

\subsection{Analysis of Impact of best practices in each city}

To represent the impact of the potential implementation of the chosen practices in the three municipalities, the energy savings calculator of the tool 'TRACE' from the World Bank was used. This calculator allows the simulation of different scenarios for each municipality, according to the selected practices. 
By adding into the software information on current and post-upgrade number of street lights, cost of electricity, average run-hours for street lighting, sector energy spend and percentage and wattage of each type of bulb used, the calculator provides results on total energy savings (in $\mathrm{GWh} /$ year), total cost savings (in \$/year) and percentage of improvement. Therefore, along with the results of the multi-criteria analysis, energy savings and financial saving scenarios are presented for each city, through a possible implementation of the selected practices.

\section{Results and discussion}

\subsection{Best practices in Public Lighting}

Table 6 shows the description of each researched practice and its impacts. The Audit Program and Guide Elaboration are combinations of the World Bank's examples of best practice through the TRACE tool, considered together in this paper due to their similarity and application in case studies of the same context. Their assumption is based on the cities that still use very inefficient lighting, with technologies of high energy consumption and a high demand for maintenance. Evaluating the system through auditing may recommend interventions that include new technologies or small changes, that increase the lifetime of luminaires and reduce maintenance costs.

\begin{tabular}{lll}
\hline Best practice & Description & Impact \\
\hline
\end{tabular}




\begin{tabular}{|c|c|c|}
\hline $\begin{array}{c}\text { A-Audit } \\
\text { Program and } \\
\text { Guide } \\
\text { Elaboration }\end{array}$ & $\begin{array}{l}\text { This practice proposes the evaluation of the existing } \\
\text { service, checking operations and maintenance, in order } \\
\text { to help to identify appropriate measures to increase } \\
\text { energy efficiency. Its main goal is to enable an overall } \\
\text { assessment of the public lighting system to identify areas } \\
\text { for improvement throughout the network. After the } \\
\text { audit, it is possible to formulate a guide that specifies } \\
\text { rules for acquiring new lamps and replacing defective } \\
\text { ones, as well as other system maintenance. }\end{array}$ & $\begin{array}{l}\text { The application of this practice can } \\
\text { contribute to energy savings, consequent } \\
\text { financial savings and reduction of carbon } \\
\text { emissions. In addition, system } \\
\text { improvements generally contribute to the } \\
\text { quality of life of the population and increase } \\
\text { the sense of public safety. }\end{array}$ \\
\hline $\begin{array}{c}B-\text { Retrofit } \\
\text { Program }\end{array}$ & $\begin{array}{l}\text { The purpose of this practice is to act in the sense of } \\
\text { renewing the public lighting system when appropriate. } \\
\text { The use of retrofits can offer the same levels of lighting } \\
\text { for lower energy consumption, also reducing carbon } \\
\text { emission and system costs, which has a longer life. } \\
\text { Moreover, this modernization contributes to reducing } \\
\text { service interruptions, improving public health and } \\
\text { safety. }\end{array}$ & $\begin{array}{l}\text { This practice, as well as the previous one, } \\
\text { contributes to energy saving, financial } \\
\text { economics, reduction of carbon emissions, } \\
\text { increased quality of life and a sense of public } \\
\text { safety. }\end{array}$ \\
\hline $\begin{array}{c}C \text { - Alternative } \\
\text { Energy } \\
\text { Program }\end{array}$ & $\begin{array}{l}\text { The use of alternative energy in public lighting is still } \\
\text { quite new, but with very positive results in cities that } \\
\text { have already adhered to this practice. Its objective is to } \\
\text { generate solar and wind energy to power the light poles, } \\
\text { ensuring greater energy security and self-sufficiency in } \\
\text { times of water crisis. }\end{array}$ & $\begin{array}{l}\text { Despite the higher initial investment, this } \\
\text { practice favours financial econom, } \\
\text { independence in terms of power generation, } \\
\text { reduction of carbon emissions and } \\
\text { contributes to more environmental } \\
\text { awareness of the population, by seeing clean } \\
\text { technologies being installed. }\end{array}$ \\
\hline $\begin{array}{c}D- \\
\text { Management } \\
\text { Program }\end{array}$ & $\begin{array}{l}\text { The main objective of tele-management is for managers } \\
\text { to have control, monitoring and remote operation of } \\
\text { public lighting through a simple and functional system. } \\
\text { This practice assists in the control of luminous intensity, } \\
\text { facilitates the integration between systems and also } \\
\text { enables the preventive action because it is possible to } \\
\text { anticipate technical problems. In addition, it can also act } \\
\text { to strategically time or dim the lights according to the } \\
\text { needs of each area, which can significantly reduce } \\
\text { energy consumption and provide adequate levels of } \\
\text { lighting (in technical and public safety terms). }\end{array}$ & $\begin{array}{l}\text { The impact of the practice is related to } \\
\text { savings in energy consumption and carbon } \\
\text { emissions, ease of maintenance because the } \\
\text { management has access to information about } \\
\text { every piece of the system and prior planning } \\
\text { is possible, as well as financial praise as a } \\
\text { consequence of the mentioned factors. Other } \\
\text { impacts include safety in terms of reducing } \\
\text { facility risk, increasing service quality and } \\
\text { tendency of short-term return on investment. }\end{array}$ \\
\hline
\end{tabular}

Table 6. Summary of the researched best practices in Public Lighting

Source: Elaboration of the authors by using information of Akker and Nhien (2011), Canadian Urban Institute (2011), EERE (2014), ESMAP (2009, 2011); PROCEL (2010), Siemens (2014), SNFOR (2016), US Department of Energy (2008), Vilaca et al. (2014), World Bank (2016a,b,c,d).

The Retrofit Program of Public Lighting aims to combat the use of inefficient lamps in public lighting. Inefficient lamps increase the consumption of electric energy by creating much more heat with comparatively little light generation in return. In addition, a lack of planning in the organization of lamps and luminaires - haphazardly dispersing light in many directions increases their inefficiency. Therefore, the use of new technologies can significantly improve the efficiency of the system, in addition to its quality.

The electricity consumed by most Brazilian cities comes from hydroelectric power, which is considered a renewable energy source. In countries with lower hydro potential, this electricity 
tends to come from non-renewable sources, such as thermoelectric and nuclear power. Regardless of the source used, it is known that the incentive to develop alternative sources is high because of the resulting energy security that can be obtained, sustainability notwithstanding. In public lighting, a practice that began to be applied recently is precisely this greater incentive to develop alternative sources for the use of solar and/or wind potential, through the Alternative Energy Program in public lighting. One challenge when it comes to this practice is to combine the positive point of sustainability with financial viability, since the initial investment is high.

The Public Lighting Management Program consists of remote controlling through applications that are connected to the internet. The use of wireless technology in the industry allows for the monitoring, control, measurement and management of the entire system, which improves its reliability and safety. Each point of light can be turned on and off at any time and a database stores its information, such as energy consumption and location. This practice also allows for the intelligent operation of the system according to weather conditions, traffic or according to the distribution network or power source, if there is more than one option. Realtime monitoring extends lamp life and indicates when maintenance service is required (Siemens, 2016). Management can also be implemented to adapt the level of lighting according to the hours of the day, the needs of the city and activities of each region, since the demand for energy for lighting the public space usually increases in the first and last hours of the evening, but with little use during the middle of the night (World Bank, 2016b).

Table 7 presents the classification of best practices according to the aspects that regulate the success of its implementation as well as the explanation of this relation.

\begin{tabular}{|l|c|}
\hline \multirow{2}{*}{ Best practice } & Framework according to Abdmouleh et al. (2015) (adapted) \\
\cline { 2 - 2 } & Aspects \\
\hline
\end{tabular}




\begin{tabular}{|c|c|c|c|c|c|}
\hline & Political & Fiscal & Financial & Legislative & $\begin{array}{l}\text { Technological } \\
\text { and } \\
\text { environmental }\end{array}$ \\
\hline $\begin{array}{c}\text { Audit Program } \\
\text { and Guide } \\
\text { Elaboration }\end{array}$ & $\begin{array}{c}\text { Greater } \\
\text { effectiveness if } \\
\text { supported by } \\
\text { National, State or } \\
\text { Municipal Plans }\end{array}$ & & $\begin{array}{c}\text { Need for } \\
\text { subsidies for } \\
\text { implementation }\end{array}$ & & $\begin{array}{l}\text { Aims at greater } \\
\text { system efficiency }\end{array}$ \\
\hline $\begin{array}{l}\text { Retrofit } \\
\text { Program }\end{array}$ & $\begin{array}{c}\text { Greater } \\
\text { effectiveness if } \\
\text { supported by } \\
\text { National, State or } \\
\text { Municipal Plans }\end{array}$ & & $\begin{array}{l}\text { Need for } \\
\text { financial } \\
\text { incentive }\end{array}$ & & $\begin{array}{l}\text { Aims at energy } \\
\text { savings }\end{array}$ \\
\hline $\begin{array}{c}\text { Alternative } \\
\text { Energy } \\
\text { Program }\end{array}$ & $\begin{array}{c}\text { Greater } \\
\text { effectiveness if } \\
\text { supported by } \\
\text { National, State or } \\
\text { Municipal Plans }\end{array}$ & $\begin{array}{l}\text { Reduction of } \\
\text { rates as a bonus } \\
\text { and incentive }\end{array}$ & $\begin{array}{l}\text { Need for } \\
\text { financial } \\
\text { incentive }\end{array}$ & & $\begin{array}{l}\text { Aims at greater } \\
\text { system efficiency }\end{array}$ \\
\hline $\begin{array}{l}\text { Management } \\
\text { Program }\end{array}$ & $\begin{array}{c}\text { Greater } \\
\text { effectiveness if } \\
\text { supported by } \\
\text { National, State or } \\
\text { Municipal Plans }\end{array}$ & & $\begin{array}{l}\text { Need for } \\
\text { financial } \\
\text { incentive }\end{array}$ & $\begin{array}{l}\text { Need for tariff } \\
\text { adjustment and } \\
\text { non-fixing of } \\
\text { lighting hours }\end{array}$ & $\begin{array}{c}\text { Aims at energy } \\
\text { savings }\end{array}$ \\
\hline
\end{tabular}

Table 7. Classification of best practices according to regulatory aspects of their success

All of the best practices present the technological and environmental aspects as regulators, as they aim for energy savings, cost savings and a more efficient lighting system and are related to the use of new technologies. The same applies to the financing and political aspect, since, depending on the size of the municipality that aims to use it, any of the listed practices may require the need for financial incentives for implementation (such as forms of financing and public or private support) The listed practices tend to be more effective if supported by municipal, state or even national energy plans, which give greater subsidies to its implementation.

The Alternative Energy Program also has a dependency on fiscal support, and municipalities that implement this practice may receive a reduction of duty rates as a bonus and incentive. In addition, the Management Program is a practice that can have better results if it is already related to legal changes, such as tariff adjustments and the need to fix daily lighting hours, which could hamper its implementation. 
When commenting on the implementation of other practices, it is important to highlight that several of these studies can or should be applied together for a better overall result. This is the case, for example when Audit foresees the retrofit, or the Management Program helps in the use of alternative energies.

\subsection{Decision-making process for choosing best practices}

After receiving the answers of the questionnaires which contained the pairwise comparisons for experts to compare and judge criteria and alternatives, the data was entered in Expert Choice 11 software. Initially the consistency of the results for each decision-maker was verified. Five of the seventeen participants had their judgments annulled (since the inconsistency radio was higher than the maximum limit allowed), in order to obtain a more reliable result.

Table 8 shows the obtained results after combining individual judgments and therefore leading to a combined final result for each municipality. Observing the overall consistency ratio of each studied city, it is noticed that the values are below 0.20 (which is the ratio considered in this paper), and also below the value of 0.10 , recommended by Saaty.

\begin{tabular}{cccc}
\hline Practices & Passo Fundo & Porto Alegre & Santa Maria \\
\hline Audit Program and Guide Elaboration & $19,3 \%$ & $\mathbf{3 6 , 7 \%}$ & $20,5 \%$ \\
Retrofit Program & $\mathbf{3 6 , 7 \%}$ & $\mathbf{3 8 , 6 \%}$ & $22,4 \%$ \\
Alternative Energy Program & $21,5 \%$ & $8,6 \%$ & $\mathbf{2 8 , 4 \%}$ \\
Management Program & $22,5 \%$ & $16,0 \%$ & $\mathbf{2 8 , 6 \%}$ \\
\hline Consistency ratio & 0,04 & 0,04 & 0,03 \\
\hline
\end{tabular}

Table 8. Results for each municipality

The sensitivity analysis is conducted by slightly altering the weights assigned to each criterion in order to verify the response in the chosen alternatives. A reliable result is observed when the obtained conclusion does not change, even with a small modification in the weights 
of the criteria. The analyses show that for changes up to $10 \%$ in the importance of the criterion - with the highest weight in each municipality (that was Energy Savings for all of them) - the results did not change significantly. It means that, in the event of the experts slightly changing their judgements, the result would still be the same.

Expert Choice software provides graphic results that help to illustrate the analysis. In the $\mathrm{X}$-axis there is the importance of the criterion, and the $\mathrm{Y}$-axis shows the percentage preference for each practice, according to the given criterion weight. For Passo Fundo, as shown in Figure 3, even though the criterion weight changed, increasing or decreasing of around 0.6 (60\%), the Retrofit Program would still be considered the major preference.

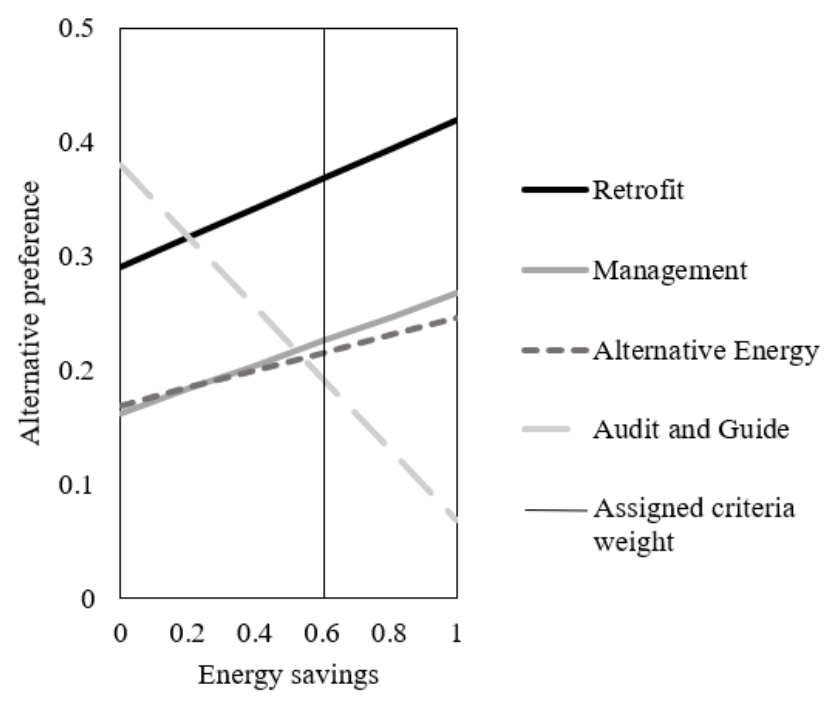

Fig. 3. Sensitivity analysis of Passo Fundo result

Figure 4 shows that, in Porto Alegre, changes in the Energy Savings criterion weight $(0.4$ or $40 \%)$ do not affect the result. In fact, for this city, there are two practices that can be considered most preferable: the Retrofit Program and Audit Program and Guide Elaboration. This is because their result is very close. It can be observed that as the importance of this criterion increases, so does the preference for the Retrofit Program practice. 


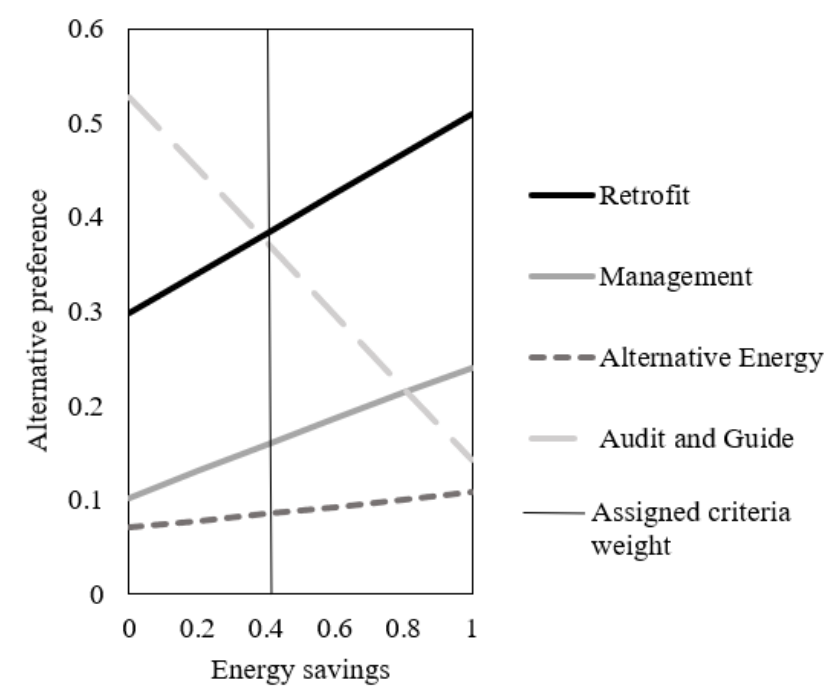

Fig. 4. Sensitivity analysis of Porto Alegre result

In Santa Maria there is also the proposal of two practices: Alternative Energy and Management Programs. This is attributed to the fact that, as shown in Figure 5, both practices have close values of importance when considering the Energy Savings criterion weight (around 0.65 or $65 \%$ ), and the same is observed if the weight slightly increases or decreases.

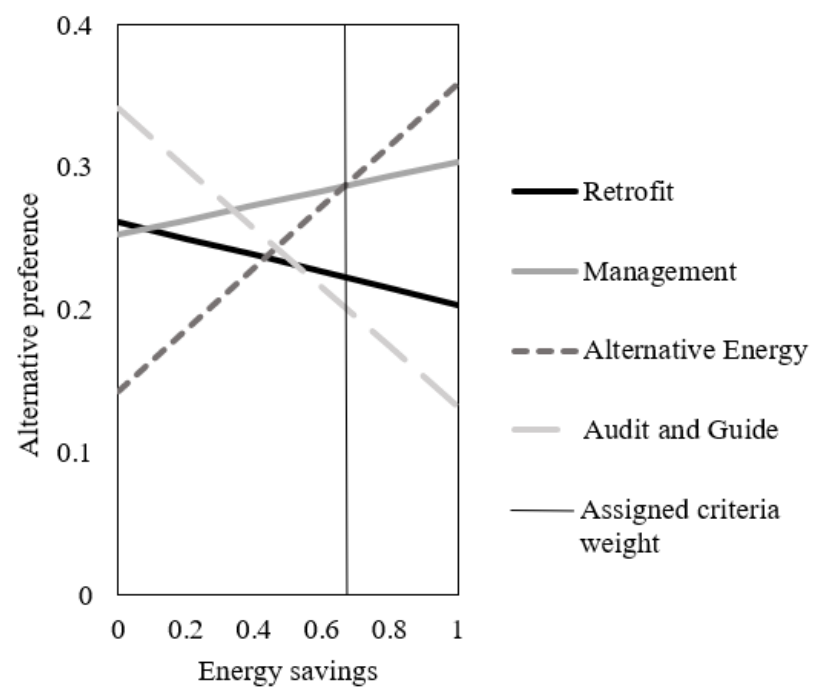

Fig. 5. Sensitivity analysis of Santa Maria result 
After confirming the reliability of the analysis, the results indicate the practices of Retrofit Program for Passo Fundo, the Audit Program and Guide Elaboration and Retrofit Program for Porto Alegre and the Alternative Energy and Management Programs for Santa Maria.

\subsection{Analysis of Impact of best practices in each city}

The use of the energy savings calculator of the TRACE tool, which allows for the simulation of changes in the public lighting system, was performed based on three post-upgrade scenarios for each city. Table 9 shows the scenarios for Passo Fundo and each one advocates for the increase in the percentage of LED bulbs used in the system. It can be observed that the higher this percentage, the greater the overall contribution to energy savings and consequently greater financial savings can be obtained. As reinforced by Rabaza et al. (2013), designing and planning efficient public lighting installations and using cost-effective tools can not solely save money but also contribute to sustainable public lighting. Specifically by using LED lamps (Djuretic and Kostic, 2018; World Bank, 2016d), the quality of the service provided improves, along with high percentage of energy savings.

\begin{tabular}{ccccc}
\hline Used lamp & Current situation (\%) & Scenario 1 (\%) & Scenario 2 (\%) & Scenario 3 (\%) \\
\hline LED & 2.4 & 10.0 & 20.0 & 30.0 \\
Sodium vapor & 96.6 & 89.0 & 78.0 & 70.0 \\
Metal halid & 1.0 & 1.0 & 1.0 & 0.0 \\
\hline Energy savings (GWh/year) & 1 & 2 & 3 \\
Financial savings (US\$year) & $74,243,50$ & $192,459.50$ & $277,143.80$ \\
\hline
\end{tabular}

Table 9. Simulation of scenarios for Retrofit Program in Passo Fundo

Table 10 shows the simulation for Porto Alegre, which is only taking the best practice of Retrofit into consideration. As for Passo Fundo, all scenarios advocate for the increase in number of LED bulbs used. The result is always positive, mainly due to the increase in the percentage of LEDs and their direct contribution to greater energy and financial savings. Despite the high investment that a lamp replacement of this magnitude would demand, the 
results suggest economical deployment feasibility, as also discussed by Irsyad and Nepal (2016) in their case studies. The design of new street lighting installations or retrofit of existing ones should take into consideration all of the available means for optimal performance (Kostic and Djokic, 2009), therefore ensuring these energy and cost savings.

\begin{tabular}{ccccc}
\hline Used lamp & Current situation (\%) & Scenario 1 (\%) & Scenario 2 (\%) & Scenario 3 $(\%)$ \\
\hline LED & 0.3 & 5.0 & 5.0 & 10.0 \\
Sodium vapor & 85.0 & 80.0 & 85.0 & 80.0 \\
Metal halid & 14.7 & 14.7 & 10.0 & 10.0 \\
\hline Energy savings (GWh/year) & 2 & 4 & 6 \\
Financial savings (US\$/year) & $242,988.10$ & 434.070 .00 & $646,815.10$ \\
\hline
\end{tabular}

Table 10. Simulation of scenarios for Retrofit Program in Porto Alegre

Table 11 presents the simulation for Santa Maria. It is important to note that in all scenarios, the use of the Alternative Energy Program increases the percentage of LED bulbs from $2 \%$ to $5 \%$, since when using this system, it is usual to apply LED technology. Therefore, the change in scenarios was limited to varying issues related to the Management Program, including the number of hours with lamps on and their level of brightness. The first and second scenarios recommend a decrease in the number of run-hours per day. Scenario 3, however, would keep the bulbs on for the same duration as they are currently, except that the brightness level would vary overnight. For five hours, the bulbs should be at maximum power $(100 \%)$, which would have normal luminosity. For approximately two hours, the bulbs should be at approximately $75 \%$ of their total brightness; and for five hours the bulbs should work at half of their potential power $(50 \%)$. 


\begin{tabular}{|c|c|c|c|c|}
\hline Lamps on & Current situation & Scenario 1 & Scenario 2 & Scenario $3 *$ \\
\hline Duration per day & $11 \mathrm{~h} 52 \mathrm{~min}$ & $10 \mathrm{~h} 52 \mathrm{~min}$ & $9 \mathrm{~h} 52 \mathrm{~min}$ & $11 \mathrm{~h} 52 \mathrm{~min}$ \\
\hline $\begin{array}{l}\text { Average run-hours } \\
\text { per year }\end{array}$ & $4330 \mathrm{~h}$ & $3970 \mathrm{~h}$ & $3600 \mathrm{~h}$ & $\begin{array}{r}1825 \mathrm{~h}(100 \%)+ \\
680 \mathrm{~h}(75 \%)+ \\
1825 \mathrm{~h}(50 \%)\end{array}$ \\
\hline \multicolumn{2}{|c|}{ Energy savings (GWh/year) } & 2 & 3 & 5 \\
\hline \multicolumn{2}{|c|}{ Financial savings (US\$/year) } & $170,005.00$ & $318,101.60$ & $501,032.15$ \\
\hline
\end{tabular}

Table 11. Simulation of scenarios for Alternative Energy and Management Programs in Santa Maria

*The average hours per year in this scenario was considered to be two equal parts divided between total system brightness $(100 \%)$ and partial luminosity $(50 \%)$ and a small part also with partial luminosity $(75 \%)$.

The third scenario is the most advantageous because of greater energy and financial savings. Its main highlight is the fact that it uses the same lighting period as the municipality currently has in place, without proposing that the lamps are turned off for a certain number of hours, but instead by ensuring greater efficiency when controlling the brightness level. As presented by Djuretic and Kostic (2018), Radulovic et al. (2011) and World Bank (2016b), projects with power regulation have proven to be feasible and lead to lower energy consumption, reduction of costs and emission of $\mathrm{CO}_{2}$, and good community perceptions.

\section{Conclusions and Policy Implications}

This paper aimed to present best practices in the field of energy efficiency in public lighting, in addition to the use of a multi-criteria method to select the ones that could be implemented in a set of studied municipalities. The limitations of this study reside on the fact that it focused on city level, the judgements were performed only by groups of engineers and the data refers exclusively to Brazil - as a case study. However, the methods used may also be applied elsewhere, especially in developing countries, since they tend to present the same weaknesses observed in Brazil, while developed countries are prone to have better infrastructure when it comes to public services. 
The result obtained for the municipality of Passo Fundo recommends for the implementation of the Retrofit Program as a practice that would contribute to the sustainable management of the sector $(36.7 \%$ of preference when compared to the others). These results corroborate with the political, financial and technological/environmental aspects of this framework made for this practice. This is because the use of technology, despite a possible need for initial investment, tends to result in environmental advantages. Legislation as an incentive for its implementation is becoming more and more important. By analyzing the impact of this practice in Passo Fundo, through the energy savings calculator, even the most conservative scenario already represents good results: by increasing the share of LED lamps in the system from $2,4 \%$ to $10 \%$, energy savings of $1 \mathrm{GWh} /$ year and financial savings of around 75.000 US\$/year can be expected.

The result obtained for Porto Alegre points to the recommendation of two practices: the Audit Program and Guide Elaboration (36.7\%) and Retrofit Program (38.6\%). As for Passo Fundo, the results are in accordance with the political, financial and technological/environmental framework of this practice. The political incentive for the success of its implementation all but guarantees subsequent environmental benefits. If Porto Alegre increases the use of LED lamps from $0.3 \%$ to $5 \%, 2$ GWh and more than US\$ 240.000,00 can be saved per year, according to the results provided by the energy savings calculator.

In Santa Maria, the recommended practices are the Alternative Energy Program (28.4\%) and the Management Program (28.6\%). In this city, all items of framing aspects are observed. The political aspect represents an incentive, mainly due to the fact that the municipality does not have a Management Plan for the sector of Public Lighting; the technological and environmental aspects are accounted for since the use of these innovative systems lead to environmentally positive results; and the financial aspect results in the implementation of the practices. In addition to these, there is the fiscal aspect, which is important because it represents 
the possibility of the municipality receiving bonuses for applying efficiency actions. There is also the legal aspect, which strongly regulates the success of the Management Program, because existing legislation sets a specific number of hours for energy consumption billing in public lighting. If there were any changes in this limit imposed by the legislation, implementation of the practice would be much more successful. The best post-upgrade scenario for Santa Maria presents energy and financial savings of $5 \mathrm{GWh} /$ year and 500.000,00 US\$/year, respectively, by suggesting the same lighting period as the current system but with different brightness levels during the night.

Energy efficiency in public lighting need to be included in local policies to guarantee its implementation. As already stated by other authors, public policy makers, among other stakeholders, need to be aware of the benefits of energy efficient lighting (Attia et al. 2017), and formulation of local policies and plans regarding efficiency in public lighting need to be integrated to local urban planning (Luong, 2015).

The recommended practices for the sustainable public lighting project in the three studied cities can support the decision of local governments, but policy makers should be aware of the autonomy of complementing or adjusting these practices in order to meet their requirements and to be coherent with the current and/or targeted setting and their local reality. In addition, the proposed methodology can be used as a key model for other cities, especially in developing countries around the world.

\section{Acknowledgments}

This study was partly financed by the Coordenação de Aperfeiçoamento de Pessoal de Nível Superior - Brasil (CAPES) - Finance Code 001. 


\section{References}

Abdmouleh Z, Alammari RAM, Gastli A. Review of policies encouraging renewable energy integration \& best practices. Renew Sust Energ Rev 2015;45:249-62.

http://dx.doi.org/10.1016/j.rser.2015.01.035

Akker J, Nhien NT. Final Evaluation: Vietnam Energy Efficiency Public Lighting. 2011, $<$ http://www.undp.org/content/dam/vietnam/docs/Project\%20Evaluations/31365_Vietnam_enener_effi ciency_public_lighting.pdf $>$. [accessed 17 mai. 2016]

Aragonés-Beltrán P, González FC, Pastor-Ferrando J, Pla-Rubio A. An AHP (Analytic Hierarchy Process)/ANP (Analytic Network Process)-based multi-criteria decision approach for the selection of solar-thermal power plant investment projects. Energy 2014;66: 222-38.

http://dx.doi.org/10.1016/j.energy.2013.12.016

Attia S, Hamdy M, Ezzeldin S. Twenty-year tracking of lighting savings and power density in the residential sector. Energy and Buildings 2017;154:113-26.

Balo F, Şağbanşua L. The Selection of the Best Solar Panel for the Photovoltaic System Design by Using AHP. Energy Procedia 2016;100:50-3. http://dx.doi.org/10.1016/j.egypro.2016.10.151

Bard JF. A comparison of the analytic hierarchy process with multiattribute utility theory: A case study. IIE transactions 1992;24(5):111-121.

Becalli M, Bonomolo M, Ciulla G, Galatioto A, Brano VL. Improvement of energy efficiency and quality of street lighting in South Italy as an action of Sustainable Energy Action Plans. The case study of Comiso (RG). Energy 2015;92:394-408. http://dx.doi.org/10.1016/j.energy.2015.05.003

Belton V, Stewart TJ. Multiple Criteria Decision Analysis: An integrated approach. Springer Science \& Business Media; 2002.

Beşikçi EB, Kececi T, Arslan O, Turan O. An application of fuzzy-AHP to ship operational energy efficiency measures. Ocean Eng 2016;121:392-402. http://dx.doi.org/10.1016/j.oceaneng.2016.05.031

Brazilian Institute of Geography and Statistics. Population. http://www.ibge.gov.br/home/, 2015. 
Briozo RA, Musetti MA. Método multicritério de tomada de decisão: aplicação ao caso da localização espacial de uma Unidade de Pronto Atendimento - UPA 24 h. Gestão \& Produção 2015;22:805-19.

Cambraia MS. Proposta de gestão da iluminação pública para municípios de pequeno a médio porte. Sinergia 2003;4(2):126-39.

Canadian Urban Institute. Municipal Policy Options Guide for Advanced Outdoor Lighting. 2011. $<$ http://static1.squarespace.com/static/546bbd2ae4b077803c592197/t/54b3ffa8e4b0fc4c2295079e/142 1082536074/CUIPublication.MunicipalLightingGuide.pdf>. [accessed 15 mai. 2016]

Carli R, Dotoli M, Pellegrino R. A Multi-Period Approach for the Optimal Energy Retrofit Planning of Street Lighting Systems. Applied Sciences 2019;9(5):1025.

Carli R, Dotoli M, Pellegrino R. A decision-making tool for energy efficiency optimization of street lighting. Computers \& Operations Research 2018;96:223-35.

Charlier D. Energy efficiency investments in the context of split incentives among French households. Energy Policy 2015;87:465-479.

Cristea M, Tîrnovan RA, Cristea C, Pică CS, Făgărășan C. A multi-criteria decision making approach for public lighting system selection. EDP Sciences. In: MATEC Web of Conferences 2018;184:04006. https://doi.org/10.1051/matecconf/201818404006

Dai H, Wang J, Li G, Chen W, Qiu B, Yan J. A multi-criteria comprehensive evaluation method for distributed energy system. Energy Procedia 2019;158:3748-53.

De Almeida A., Santos B, Paolo B, Quicheron M. Solid state lighting review-Potential and challenges in Europe. Renew Sust Energ Rev 2014;34:30-48. http://dx.doi.org/10.1016/j.rser.2014.02.029

Djuretic A, Kostic M. Actual energy savings when replacing high-pressure sodium with LED luminaires in street lighting. Energy 2018;157:367-78.

Doumpos M, Grigoroudis E. Multicriteria decision aid and artificial intelligence: links, theory and applications. John Wiley \& Sons, 2013. 
EERE. DOE Street Lighting Consortium Releases Results of Public Street and Area Lighting Inventory Survey. 2014, http://energy.gov/eere/ssl/articles/doe-street-lighting-consortium-releasesresults-public-street-and-area-lighting, [accessed 20 mai. 2016].

Emrouznejad A, Marra M. The state of the art development of AHP (1979-2017): a literature review with a social network analysis. Int J Prod Res 2017;1-23.

http://dx.doi.org/10.1080/00207543.2017.1334976

Energy Research Enterprise. The Brazilian Yearbook of Electricity.

http://www.epe.gov.br/AnuarioEstatisticodeEnergiaEletrica/Anu\%C3\%A1rio\%20Estat\%C3\%ADstico \%20de\%20Energia\%20El\%C3\%A9trica\%202015.pdf, 2015.

ESMAP. Good practices in city energy efficiency: Akola Municipal Corporation, India Performance Contracting for Street Lighting Energy Efficiency. 2009, http://www.esmap.org/sites/esmap.org/files/CS_India_SL_Akola_020910.pdf, [accessed 15 apr. 2016]

ESMAP. Good practices in city energy efficiency: Los Angeles, USA - Light Emitting Diode (LED) Street Lighting Retrofit. 2011, http://www.esmap.org/sites/esmap.org/files/LosAngeles_LED_final_edited_11-9-11.pdf, [accessed 15 apr. 2016]

ESMAP. TRACE: Tool for rapid Assessment of City Energy. The World Bank Group, 2013, http://www.esmap.org/sites/esmap.org/files/ESMAP_EECI_TRACE_Brochure_2013.pdf., [accessed 28 abr. 2016].

ESMAP. Tool for Rapid Assessment of City Energy, 2016, http://esmap.org/TRACE, [accessed 30 mar. 2016].

European Commission. Best practice: a method for dissemination and implementation of project results. 2005,

http://ec.europa.eu/environment/life/publications/lifepublicationsgeneralpublications/docudocum/bestp ractice.pdf. [accessed 18 dez. 2015].

Fonseca CC, Pantoni RP, Brandão D. Public street lighting remote operation and supervision system. Computer Standards \& Interfaces 2015;38:25-34. 
Franek J, Kresta A. Judgment scales and consistency measure in AHP. Procedia Economics and Finance 2014;12:164-73. http://dx.doi.org/10.1016/S2212-5671(14)00332-3

Gracioso F, Najjar ER. Siemens: Revisão da estratégia de gestão de pessoas. Central de Cases ESPM, 2001. http://www.espm.br/Publicacoes/Central DeCases/Documents/SIEMENS.pdf. [accessed 21 out. 2015].

Green J, Perkins C, Steinbach R, Edwards P. Reduced street lighting at night and health: a rapid appraisal of public views in England and Wales. Health \& place 2015;34:171-80.

Hamurcu M, Eren T. An Application of Multicriteria Decision-making for the Evaluation of Alternative Monorail Routes. Mathematics. 2019;7(1):16.

Havas L, Ballweg J, Penna C, Race D. Power to change: Analysis of household participation in a renewable energy and energy efficiency programme in Central Australia. Energy Policy 2015;87:32533.

Irsyad MI, Nepal R. A survey based approach to estimating the benefits of energy efficiency improvements in street lighting systems in Indonesia. Renew Sust Energ Rev 2016;58:1569-77. http://dx.doi.org/10.1016/j.rser.2015.12.294

Ishizaka A, Siraj S, Nemery P. Which energy mix for the UK (United Kingdom)? An evolutive descriptive mapping with the integrated GAIA (graphical analysis for interactive aid)-AHP (analytic hierarchy process) visualization tool. Energy 2016;95:602-11.

http://dx.doi.org/10.1016/j.energy.2015.12.009

Jollands N, Kenihan S, Wescott W. Promoting Energy Efficiency Best Practices in Cities. International Energy Agency, Paris, 2008.

Jovanović B, Filipović J, Bakić V. Prioritization of manufacturing sectors in Serbia for energy management improvement-AHP method. Energ Convers Manage 2015;98:225-35. http://dx.doi.org/10.1016/j.enconman.2015.03.107 
Kavousian A, Rajagopal R, Fischer M. Ranking appliance energy efficiency in households: Utilizing smart meter data and energy efficiency frontiers to estimate and identify the determinants of appliance energy efficiency in residential buildings. Energy and Buildings 2015;99:220-30.

Karthikeyan R, Venkatesan KGS, Chandrasekar A. A Comparison of Strengths and Weaknesses for Analytical Hierarchy Process. Journal of Chemical and Pharmaceutical Sciences 2016;9(3):12-15.

Kostic M, Djokic L. Recommendations for energy efficient and visually acceptable street lighting. Energy 2009;34:1565-72. http://dx.doi.org/10.1016/j.energy.2009.06.056

Kumar A, Sah B, Singh AR, Deng Y, He X, Kumar P, Bansal RC. A review of multi criteria decision making (MCDM) towards sustainable renewable energy development. Renew Sust Energ Rev 2017;69:596-609.

Kurka T. Application of the Analytic Hierarchy Process to evaluate the regional sustainability of bioenergy developments. Energy 2013;62:393-402. http://dx.doi.org/10.1016/j.energy.2013.09.053

Leal Filho W, Voudouris V. (Eds) Global Energy Policy and Security. London: Springer; 2013.

Lobão JA, Devezas T, Catalão JPS. Energy efficiency of lighting installations: Software application and experimental validation. Energy Reports 2015;1:110-15.

http://dx.doi.org/10.1016/j.egyr.2015.04.001

Luong ND. A critical review on energy efficiency and conservation policies and programs in Vietnam. Renewable and Sustainable Energy Reviews 2015;52:623-34.

Marinakis V, Doukas H, Xidonas P, Zopounidis C. Multicriteria decision support in local energy planning: an evaluation of alternative scenarios for the sustainable energy action plan. Omega 2017;69:1-6.

Miguel AS, Zamorano J, Castaño JG, Pascual S. Evolution of the energy consumed by street lighting in Spain estimated with DMSP-OLS data. Journal of Quantitative Spectroscopy and Radiative Transfer 2014;139:109-17. 
Oguzitimur S. Why fuzzy analytic hierarchy process approach for transport problems? In: European Regional Science Association ERSA Conference Papers, Barcelona, Spain, European Regional Science Association (ERSA), 2011.

Özkara Y, Atak M. Regional total-factor energy efficiency and electricity saving potential of manufacturing industry in Turkey. Energy 2015; 93:495-510.

Peña-García A, Hurtado A, Aguilar-Luzón MC. Impact of public lighting on pedestrians' perception of safety and well-being. Safety science 2015;78:142-8.

Peng L, Zhang Y, Wang Y, Zeng X, Peng N, Yu A. Energy efficiency and influencing factor analysis in the overall Chinese textile industry. Energy 2015;93:1222-9.

PROCEL. Casos de sucesso. 2010, http://www.procelinfo.com.br/services/procelinfo/Simuladores/DownloadSimulator.asp?DocumentID=\%7B650BA0F4-DA0E-4185-A4C998A9A0B9A675\%7D\&ServiceInstUID=\%7B5F6B86BE-D506-46B2-BED6-EF2283918831\%7D>. [accessed 10 mar. 2016].

Rabaza O, Peña-García A, Pérez-Ocón F, Gómez-Lorente D. A simple method for designing efficient public lighting, based on new parameter relationships. Expert Syst Appl 2013;40:7305-15. http://dx.doi.org/10.1016/j.eswa.2013.07.037

Rabaza O, Gómez-Lorente D, Pérez-Ocón F, Peña-García A. A simple and accurate model for the design of public lighting with energy efficiency functions based on regression analysis. Energy 2016;107:831-42.

Radulovic D, Srdjan S, Kirincic V. Energy efficiency public lighting management in the cities. Energy 2011; 36:1908-15. http://dx.doi.org/10.1016/j.energy.2010.10.016

Ramanathan R, Ganesh LS. Energy resource allocation incorporating qualitative and quantitative criteria: an integrated model using goal programming and AHP. Socio-Econ Plan Sci 1995;29:197218.

Ramanathan R. Multicriteria Analysis of Energy. Encyclopedia of Energy 2004, 77-88, https://doi.org/10.1016/B0-12-176480-X/00240-0 
Salvia, AL. Eficiência energética em iluminação pública na gestão sustentável de cidades: estudo de multicasos. 2016. 160 f (Doctoral dissertation) Universidade de Passo Fundo, Passo Fundo. http://tede.upf.br/jspui/handle/tede/1402 [accessed 10 mar. 2019].

Saaty TL. Fundamentals of decision making and priority theory with the Analytic Hierarchy Process. 1st ed. RWS Publications: 1994.

Saaty TL. Decision making with the analytic hierarchy process. Intern J Serv Sci 2008; 1:83-98.

Saaty TL. Some mathematical concepts of the analytic hierarchy process. Behaviormetrika 1991;18(29): 1-9.

Scala NM, Needy KL, Rajgopal J. Using the Analytic Hierarchy Process in group decision making for nuclear spare parts. Proc 31st Annu ASEM Natl Conf, 2010.

Siemens. Intelligent Street Lighting. Germany, 2014.

https://www.mobility.siemens.com/mobility/global/SiteCollectionDocuments/en/roadsolutions/services/intelligent-streetlighting-en.pdf. [accessed 10 jan. 2016].

Siemens. Street Lighting: Additional offering for municipal infrastructure. 2016.

http://w3.siemens.com/markets/global/en/municipalities-dsos/offerings/pages/street-lighting.aspx. [accessed 10 jan. 2016].

Silva AS, Almeida LS, Ghisi E. Decision-making process for improving thermal and energy performance of residential buildings: A case study of constructive systems in Brazil. Energy and Buildings 2016;128:270-86.

SNFOR. KL-Karak Highway. <http://snfor.com/portfolio/road/kl-karakhighway/>. [accessed 23 mai. 2016].

Strantzali E, Aravossis K. Decision making in renewable energy investments: A review. Renewable and Sustainable Energy Reviews 2016;55:885-98.

Sui L, Ju Y, Yang Y, Yang Y, Li A. A quantification method for shale fracability based on analytic hierarchy process. Energy 2016;115:637-45. http://dx.doi.org/10.1016/j.energy.2016.09.035 
Tang Y, Sun H, Yao Q, Wang Y. The selection of key technologies by the silicon photovoltaic industry based on the Delphi method and AHP (analytic hierarchy process): Case study of China. Energy 2014;75:474-82. http://dx.doi.org/10.1016/j.energy.2014.08.003

Ulloa C, Nuñez JM, Lin C, Rey G. AHP-based design method of a lightweight, portable and flexible air-based PV-T module for UAV shelter hangars. Renewable Energy 2018;123:767-80.

U.S. Department of Energy. Demonstration Assessment of Light Emitting Diode (LED) Street Lighting. 2008. $<$ http://energy.gov/sites/prod/files/2014/05/f15 emerging_tech_report_led_streetlighting.pdf $>$. [accessed 10 mai. 2016]

Vilaca NMA, Figueiredo VN, Oliveira LB, Ferreira VH, Fortes MZ, Correia WF, et al. Smart City Caso Da Implantação Em Buzios - RJ. Sodebras 2014;9(98):16-22.

Webber P, Gouldson A, Kerr N. The impacts of household retrofit and domestic energy efficiency schemes: A large scale, ex post evaluation. Energy Policy 2015:84:35-43.

World Bank. Gross Domestic Product Data. http://data.worldbank.org/country/brazil, 2015.

World Bank. Integrated Public Lighting Assessment Program. Recommendations. TRACE, 2016a.

World Bank. Lighting Timing Program. Recommendations. TRACE, $2016 \mathrm{~b}$.

World Bank. Procurement Guide for New Street Lights. Recommendations. TRACE, 2016c.

World Bank. Street Lighting Audit and Retrofit Program. Recommendations. TRACE, 2016d.

Yagmur L. Multi-criteria evaluation and priority analysis for localization equipment in a thermal power plant using the AHP (analytic hierarchy process). Energy 2016;94:476-82. http://dx.doi.org/10.1016/j.energy.2015.11.011

Zambon KL, Carneiro AAF, Silva ANR, Negri JC. Análise de decisão multicritério na localização de usinas termoelétricas utilizando SIG. Pesquisa Operacional 2005; 25(2):183-99. 